\title{
Effect of sucrose on denitrification through simulation, lab-scaled batch tests and pilot plants
}

\section{- Anh Duc Phung}

- M. Othman

- J. Yulian

RMIT, Melbourne, VIC, Australia

(Manuscript received on $23^{\text {rd }}$ September 2014, accepted on $22^{\text {nd }}$ December 2014)

\section{ABSTRACT}

The aim of this study was to assess the impact of sucrose as external carbon source on denitrification. The specific denitrification rate (SDNR) determined using batch tests showed that acclimation to sucrose can increase SDNR in post and pre-anoxic denitrification zones by $47 \%$ and $116 \%$, respectively. The use of sucrose in pre-anoxic zone led to an SDNR of $2.72 \pm 0.15 \mathrm{mg} \mathrm{NO}_{3}{ }^{-}$ $\mathrm{N} / \mathrm{g} \mathrm{MLVSS} / \mathrm{h}$. This is 2.1 times higher than in the absence of external carbon and 1.7 times higher than the SDNR when sucrose was added into post-anoxic zone.

The experiment has also tested the effect of sucrose on a pre-anoxic denitrification system with low carbon-to-nitrogen ratio $(C / N)$ influent of 7.2 by adding roughly $150 \mathrm{mgCOD} / \mathrm{L}$ of sucrose into the pre-anoxic zone. This was done through two simulation modellings before the results were verified with a pilot plant trial run. The two simulation models (a basic conceptual model and Biowin) showed a drop of effluent $T N$ from $31.8 \pm 8 \mathrm{mg} / \mathrm{L}$ to $17.7 \pm 2.2$ $\mathrm{mg} / \mathrm{L}$ and $23.7 \pm 10.3 \mathrm{mg} / \mathrm{L}$ respectively. While the pilot plant test showed a clear drop from $32.7 \pm 4.7 \mathrm{mg} / \mathrm{L}$ down to $17.7 \pm 5.5 \mathrm{mg} / \mathrm{L}$ after adding sucrose. The result showed that the conceptual model was providing a more accurate simulation run than the Biowin model in this case.

Keywords: Denitrification, external carbon source, Biowin, simulation

\section{INTRODUCTION}

The availability of organic carbon is one of the key elements for complete denitrification as it is often the limiting substrate for this process $[1,2,3]$. Although the Modified Ludzack-Ettinger (MLE) uses the influent as a carbon source, preanoxic denitrification could still be limited due to the lack of readily biodegradable chemical oxygen (rbCOD) in the influent and the low specific denitrification rate (SDNR) of influent organic carbon.

Alternatively, adding an external carbon source into post- or pre-anoxic zone allows for increased denitrification, while requires little modifications of an existing WWTP. It's also easy to implement, and can meet both the short and long-termed treatment standard. There have

Trang 22 
been many studies on the viability of different carbon sources to enhance denitrification. Generally, methanol is the most used and documented carbon source [4], and was recommended by the US EPA as the most appropriate choice for additional substrate because of their availability, low production of sludge, and no additional nitrogen would be introduced into the system. However for large WWTPs, the cost for methanol can significantly increase operating costs. Hence, finding an alternative cost-effective external carbon substance is amongst the priorities of the wastewater treatment industry for the past two decades [1].

There have been many researches on materials rich in carbon, such as industrial

\section{MATERIALS AND METHODS}

\section{Synthetic wastewater components}

The sucrose used in this experiment was a by-product of sugar industrial process, is a light yellow, fairly stable liquid with a COD constant of $10^{6} \mathrm{mg} / \mathrm{L}$ despite storing in room temperature for months. This sucrose solution was diluted previous to being added into the batch experiments or trial pilot plant study. Potassium nitrate, ammonia chloride, potassium hydrogen orthophosphorus used in the batch test was from Science Supply Australia.

\section{Operating conditions}

The influent characteristics and pilot plant physical data was measured three times a week and summarised as below. These parameters were also used as data input for Biowin and the conceptual model (see table 1).

The operation parameters such as SRT, HRT and Internal Recycle Rate were picked to model wastewater, corn starch, reject water (cited in [5], syrup from distillery waste product [6] food industries, studied and cited in [4]. Many of these wastes were found to provide effective denitrification, but its availability tends to be regional and is the limiting factors.

Similarly, this study will look at industrial graded sucrose, mainly due to its availability locally as a by-product rich in carbon. The main objectives would be to assess the use of industrial graded sucrose as an external carbon source for denitrification, through determining SDNR of post and pre-anoxic zone and set up different model to simulate a pre-anoxic denitrification case study.

after a pre-anoxic municipal WWTP of 10 ML/day capacity. The same wastewater treatment plant where the pilot plant was located

\section{Denitrifying Biomass}

The sludge rich in denitrifying biomass used in the batch tests was obtained from local WWTP. The sludge was collected from the preanoxic zone, transported in ice box to the lab where it was sieved to remove any large particles. It was then used for the experiment immediately, unless sucrose-acclimation was required. To create sucrose-acclimated sludge, the sludge was fed with sucrose (COD approximately $2000 \mathrm{mg} / \mathrm{L}$ ) and aerated to maintain a higher than $3.0 \mathrm{mgDO} / \mathrm{L}$ at room temperature $\left(23-26^{\circ} \mathrm{C}\right)$ overnight for 24 hours. The sludge supernatant was tested to ensure all COD was used up before using it in the experiments. 
Table 1. Pilot plant characteristics

\begin{tabular}{|l|l|l|}
\hline Influent Parameters & & Average \\
\hline Influent TN & - average & $82.3 \pm 16.5 \mathrm{mg} / \mathrm{L}$ \\
& - during $1^{\text {st }}$ month & $77.8 \pm 8.3 \mathrm{mg} / \mathrm{L}$ \\
& - during sucrose trial & $88.59 \pm 10.82 \mathrm{mg} / \mathrm{L}$ \\
\hline Influent COD & - average & $595 \pm 110 \mathrm{mg} / \mathrm{L}$ \\
& - during $1^{\text {st }}$ month & $552 \pm 108 \mathrm{mg} / \mathrm{L}$ \\
& - during sucrose trial & $620 \pm 99 \mathrm{mg} / \mathrm{L}$ \\
\hline MLSS (anoxic tank) & & $1660 \pm 180 \mathrm{mg} / \mathrm{L}$ \\
\hline Temperature & & $20-26.5^{\circ} \mathrm{C}$ \\
\hline Operation parameters & & Average \\
\hline SRT & & $11-12$ days \\
\hline HRT (total) & & 30 hours \\
\hline Internal recycle rate & & 4 times \\
\hline
\end{tabular}

\section{Analytical Method}

COD, TN, Ammonia and Nitrate were analysed using $\mathrm{HACH}$ standard methods for the DR 5000 (Methods 8000, 10072, 10031 and 10020 respectively). $\mathrm{pH}$ and DO were tested using the Mettler Toledo S20 Seveneasy $\mathrm{pH}$ meter and YSI 5100 dissolved oxygen meter.

\section{SDNR Batch Tests}

The SDNR batch test method was developed based on the method described in [5] and [7]. The sludge collected from the nitrification stage of a WWTP plant was spiked with excessive nitrate and a designated dosage of the carbon sources (sucrose and/ or wastewater). Nitrate concentration was monitored for 2 to 3.5 hours depending on the type of batch tests. The DO was also monitored and found to be in the range of $0.18-0.20 \mathrm{mg} / \mathrm{L}$ during the running of the experiment. The SDNR, also the maximum specific denitrification rate of tested carbon, was calculated from the slope of removed $\mathrm{NO}_{3}-\mathrm{N}$ concentration [7].

The results of the first 60 minutes were recorded but ignored in the calculation to make sure the batch test reaches stability. Theoretically, if a straight line was obtained, the SDNR will equal (where $\mathrm{V}=$ volume of the reactor, and $\mathrm{t}=$ reaction time):

$$
S D N R=\frac{\Delta\left(\mathrm{NO}_{3} \cdot \mathrm{N}+0.6 \mathrm{NO}_{2} \cdot \mathrm{N}\right)}{M L V S S \times V \times t}
$$

However in this case the SDNR was calculated using the slope of line-of-best-fit over all data points. Originally nitrite was also tested, but during sample runs, an insignificant amount was detected due to its instability, so nitrite sampling was omitted from this experiment.

The batch test used in this paper is a $1 \mathrm{~L}$ of anoxic reactor, consists of $200 \mathrm{~mL}$ of settled sludge from the nitrification stage of Sunbury WWTP. This provides an MLVSS of 1000-2200 $\mathrm{mg} / \mathrm{L}$ depending on the sludge match.. Notably, the MLVSS inside each reactor does not needed to be exact, as the difference in mixed liquor biomass may affect the overall denitrification removal, but will not affect the calculated SDNR [8].

Roughly 400mg COD of the test carbon (wastewater influent, sucrose, or mixed of the two ) was added into each of the $1 \mathrm{~L}$ reactor. The

\section{Trang 24}


differences between them are: the batch experiment using mixture of sucrose and influent will indicate the effect of sucrose on a pre-anoxic denitrification system (where a carbon source comes from both sucrose and the influent stream). On the other hand, the batch experiments on sucrose alone will indicate the effect of sucrose on a post-anoxic denitrification system, as by this stage the organic carbon from influent would have already been used up.

Potassium nitrate, ammonia chloride, potassium hydrogen orthophosphorus were added into the sludge slurry such that a concentration of $30 \mathrm{mg} \mathrm{NO}{ }_{3}-\mathrm{N} / \mathrm{L}, 35 \mathrm{mg} \mathrm{NH} 4-\mathrm{N} / \mathrm{L}$ and $9 \mathrm{mg} \mathrm{P_{4 } -}$ $\mathrm{P} / \mathrm{L}$, respectively, would be achieved in each reactor. This should provide excessive nutrient sources for denitrification process to reach its maximum rate [7].

The reactor was mixed gently and semicovered to limit contact to the atmosphere, hence minimise the chance of nitrification to occur. DO probe was used to monitor the DO level inside each reactor. Nitrate and COD samples were taken and analysed every half hour toward the end. MLSS and ammonia was tested before and at the end of the experiment, the later was to ensure limited nitrification has occurred.

The batch tests were operated in different temperatures and converted back to $20^{\circ} \mathrm{C}$ using [9] :

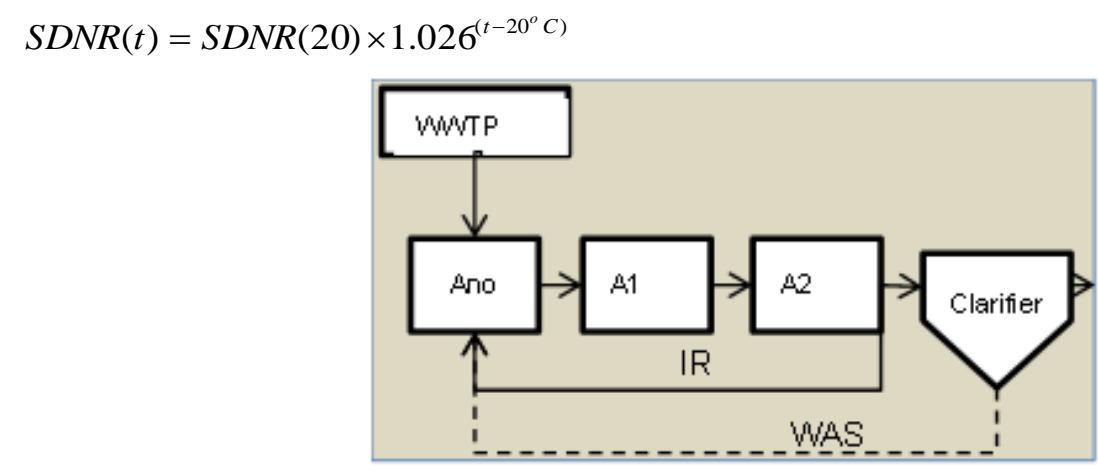

Figure 1. Schematic diagram of the pilot plant. Note: Ano = anoxic tank, A1 = first aerobic tank, A2 = second

aerobic tank, IR= internal recycle flow, WAS: recycled wasted activated sludge
Based on the SDNR of the system, a simple conceptual model based on $\mathrm{N}$ cycle could then be built to predict the denitrification performance of the pilot-scale system. The SDNR batch tests have been implemented in the Environmental Engineering Laboratory within RMIT, Melbourne, Australia.

\section{Pilot-scale plant}

A pilot plant of an MLE process was set up. It is a standard MLE set-up with the internal recycled flow being pumped from the end of the aerobic zone back to the anoxic zone for denitrification. The pilot plant was to model a pre-anoxic municipal WWTP of 10 ML/day capacity. The diagram of the pilot-plant set up is shown in Figure 1.

Each tank holds an effective volume of approximately 37L, with the first tank being anoxic, and the second and third tanks are aerobic (DO>3 mg/L). The influent flow rate is approximately $3.5-3.8 \mathrm{~L} / \mathrm{h}$, making a HRT of roughly 10 hours for each tank. The SRT was about 11.5 days.

As the temperature inside the reactor at night could drop down to as low as $10{ }^{\circ} \mathrm{C}$, which may affect up to $60-70 \%$ of denitrifier growth rate and denitrification rate [5]. A heater was also used to heat and keep the temperature inside the reactor to be $>15^{\circ} \mathrm{C}$ 
The pilot plant has been running for more than a year, but the data collected for this specific experiment was only for 2 months. For the first month, no external carbon source was used. During the second month, sucrose solution was pumped into the anoxic tank to increase the influent rbCOD by $170 \mathrm{mg}$ COD/L. The pilot plant performance was monitored and the effect of sucrose on the system denitrification was assessed. The tests on the pilot plant have been implemented in the Environmental Engineering Laboratory within RMIT, Melbourne, Australia.

\section{Simulation}

\section{RESULTS AND DISCUSSIONS}

\section{Specific denitrification rate (SDNR) batch tests for non-acclimated sludge}

Using the SDNR batch test method as described in Section 2.4, for the first series of batch tests, three types of carbon sources ,
The used Biowin Simulation was a dynamic model modelling the Pilot plant performance. The physical and operational input data was set using the pilot plant actual physical and operational parameters. Influent characteristics were based on real wastewater data measured over the two months period. The default kinetic and stoichiometry constants available in Biowin (for standard municipal activated sludge processes) were used,

The pilot plant performance during the second month was modelled by adding another $170 \mathrm{mg} \mathrm{rbCOD} / \mathrm{L}$ into the first tank.

sucrose, raw wastewater and a mixture of sucrose:raw wastewater at 50:50, were tested using non-acclimated sludge (sludge not yet acclimate to sucrose). The SDNR obtained are summarised in Table 2.

Table 2. SDNR for non-acclimated sludge

\begin{tabular}{|l|c|c|c|}
\hline Carbon source & $\begin{array}{c}\mathrm{SDNR}\left(20^{\circ} \mathrm{C}\right) \\
\left(\mathrm{mg} \mathrm{NO}_{3}-\mathrm{N} / \mathrm{g}\right. \\
\mathrm{MLVSS} / \mathrm{h})\end{array}$ & $\mathrm{R}^{\wedge} 2$ & $\begin{array}{c}\text { Consumed carbon for } \\
\text { every mgNO3 removed }\end{array}$ \\
\hline $\mathrm{A}(\mathrm{ns})$ & 1.10 & 0.8413 & 6.2 \\
\hline $\mathrm{B}(\mathrm{nw})$ & 1.29 & 0.8803 & 4.7 \\
\hline $\mathrm{C}(\mathrm{n} 50)$ & 1.27 & 0.9911 & 6.1 \\
\hline
\end{tabular}

Where A(ns) : sucrose is the only source of COD.

$\mathrm{B}(\mathrm{nw})$ : wastewater is the only source of COD.

C (n50) : sucrose and wastewater each contribute $50 \%$ of the COD.

The SDNR obtained using batch tests and sucrose as a carbon source (Test A) is $1.10 \mathrm{mg}$ $\mathrm{NO}_{3}-\mathrm{N} / \mathrm{g}$ MLVSS/h. This result is in agreement with the reported SDNR in literature [10] using sucrose where the trend there also showed that SDNR for non-acclimated sludge to be roughly 1.1. The SDNR using wastewater as the carbon source (Test B) was $1.29 \mathrm{mg} \mathrm{NO}-\mathrm{N} / \mathrm{g}$ MLVSS/h units is close to the tehoretical SDNR of 1.25 caculated from [9].
The SDNR using a mixture of wastewater: sucrose (50:50 ratio) as a carbon source (Test C) was $1.27 \mathrm{mg} \mathrm{NO}-\mathrm{N} / \mathrm{g}$ MLVSS/h which is almost the same rate with Test $\mathrm{B}$, indicating that there is minimal effect of sucrose on non-acclimated sludge. The only major differnce is that: it showed a much more stable denitrification rate (with a $\mathrm{R}^{2}$ of more than 0.99) and have higher carbon consumption rate for every $\mathrm{mg}$ of $\mathrm{N}$ removed than $B$

\section{Trang 26}




\section{SDNR batch tests for sucrose- acclimated sludge}

There has been many studies that evaluated the SDNR in the presence of external carbon sources $[5,8,11,12]$. These studies showed that the SDNR usually increases when the sludge biomass was left to be acclimated with the specific carbon source. This section hence will assess the effect of acclimation to the SDNR of sucrose.

Table 3. SDNR using acclimated sludge

\begin{tabular}{|l|c|c|c|}
\hline & $\begin{array}{c}\mathrm{SDNR}\left(20^{\circ} \mathrm{C}\right) \\
\left(\mathrm{mg} \mathrm{NO}_{3}-\mathrm{N} / \mathrm{g} \mathrm{MLVSS} / \mathrm{h}\right)\end{array}$ & $\mathrm{R}^{\wedge} 2$ & $\begin{array}{c}\text { Consumed COD for } \\
\text { every mg NO}\end{array}$ \\
\hline $\mathrm{D}$ (as) & $\mathbf{1 . 6 4} \pm \mathbf{0 . 1 8}$ & $0.941-0.977$ & $3.4-4.4$ \\
\hline $\mathrm{E}$ (a50) & $\mathbf{2 . 7 2} \pm \mathbf{0 . 1 5}$ & $0.959-0.997$ & $5.1-7.0$ \\
\hline
\end{tabular}

Where, $\mathrm{D}(\mathrm{as})$ : sucrose is the only source of COD.

$\mathrm{E}(\mathrm{a} 50)$ : sucrose and wastewater each contribute $50 \%$ of the COD.

The batch test was done in three different set of temperatures with duplicates, and then converted to SDNR at $20{ }^{\circ} \mathrm{C}$. Using acclimated sludge, the SDNR in the presence of only sucrose increased to 1.64 , compared to 1.1 using non acclimated sludge. The maximum rate of 1.8 is also closer to the figure found in literature [10] for sucrose after the sludge was acclimated. The acclimated SDNR of the mixed sucrose and wastewater solutions however increased much more significantly, from 1.27 to 2.72. As seen, this rate is much higher than the SDNR of acclimated sucrose or wastewater alone (Experiment D and B), and even close to the total of those two.

Two conclusions can be drawn from these results. Firstly they showed the significance of acclimation to SDNR of external carbon source (sucrose in this case). And secondly the result has provided interesting take on how a mixed stream of sucrose and wastewater as carbon sources will provide much higher denitrification rate than either alone.
As the original plan to test the SDNR of the mixture sucrose and wastewater was to test the effect of sucrose when adding into pre-anoxic zone of an MLE, in oppose to sucrose only in post-anoxic zone (when the COD of the wastewater influent has already been depleted). The results of this study may means adding sucrose into the pre-anoxic may product a higher SDNR than at post-anoxic zone.

\section{Pilot plant influent data and simulations}

The influent and effluent characteristics of the pilot plant before adding sucrose are summarised in Table 1.

A simple conceptual model for the pilotplant based on above physical pilot plant characteristic and nitrogen balance can be set up as shown in Figure 2. This model assumes the system has complete ammonification ( the broken down of organic nitrogen into ammonia), nitrification and denitrification. 


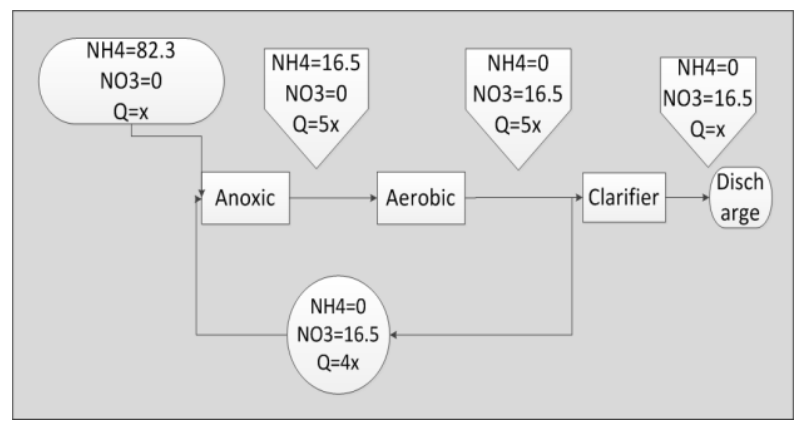

Figure 2. Conceptual model of the pilot plant

The model showed that the first anoxic zone has to denitrify more than $16.5 \pm 2.5 \mathrm{mg} \mathrm{NO} 3-\mathrm{N} / \mathrm{L}$ (or $17.7 \pm 2.1 \mathrm{mg} \mathrm{NO} \mathrm{NO}_{3}-\mathrm{N} / \mathrm{L}$ during sucrose trial period) to completely remove nitrate from internal recycle flow and prevent nitrate accumulation within the system. Based on the SDNR from the batch tests, the amount of removed nitrate during the first cycle of the anoxic zone that can be calculated using:
$\mathrm{NO}_{3}$ removed $=\frac{S D N R(20)}{1.026^{(20-T)}} \times M L S S \times H R T$

Take the temperature to be $15 \mathrm{oC}$ based on the set temperature from the heater. The denitrification limit (the highest amount of nitrate that can be removed) of the first anoxic tank can be calculated based on gotten SDNR in Table 3 previous section as below.

Table 4. The denitrification limit of the first anoxic tank using various carbon sources

\begin{tabular}{|l|c|}
\hline & Denitrification limit of the $1^{\text {st }}$ anoxic ta \\
\hline $\begin{array}{l}\text { Do not add sucrose } \\
\text { (carbon source is from influent only) }\end{array}$ & $18.9 \pm 2.1 \mathrm{mg} \mathrm{NO}_{3}-\mathrm{N} / \mathrm{L}$ \\
\hline Add sucrose, non-acclimated sludge & $18.5 \pm 2.1 \mathrm{mg} \mathrm{NO}_{3}-\mathrm{N} / \mathrm{L}$ \\
\hline Add sucrose, acclimated sludge & $40.0 \pm 4.3 \mathrm{mg} \mathrm{NO}_{3}-\mathrm{N} / \mathrm{L}$ \\
\hline
\end{tabular}

As without adding sucrose, the denitrification of the first anoxic tank is $16.8-21.0 \mathrm{mg} \mathrm{NO} \mathrm{NO}_{3} \mathrm{~N} / \mathrm{L}$, the range still overlaps with the needed $14.0-19.0 \mathrm{mg}$ $\mathrm{NO}_{3}-\mathrm{N} / \mathrm{L}$ or $15.6-19.8 \mathrm{mg} \mathrm{NO}-\mathrm{N} / \mathrm{L}$ required for complete denitrification. It's hence unlikely that complete denitrification will occur; and the conceptual model predicted there will be nitrate accumulation inside the system over time.

If however sludge could acclimate to sucrose before sucrose is pumped into the first anoxic zone, then the denitrification limit will be much higher than the needed for complete nitrate removal. Hence complete denitrification will occur. And if there was complete ammonification and nitrification in the aerobic zone (and no denitrification happened inside the clarifier), the expected effluent $\mathrm{TN}$ and $\mathrm{NO}_{3}-\mathrm{N}$ during the sucrose trial run will be17.7 $\pm 2.1 \mathrm{mg} / \mathrm{L}$

A Biowin simulation was also run using physical data of the pilot plant in table 1 and dynamic influent based on periodic sampling and analysis. All microbiology and stoichiometry constants used were Biowin default values. The results are compared and summarised in Table 6.

\section{Pilot scale tests}

The results of this trial run can be summed up in Table 5 below:

Trang 28 
Table 5. Nitrogen Removal in the Pilot Plant

\begin{tabular}{|l|c|c|}
\hline & Before adding sucrose & After adding sucrose \\
\hline Effluent TN & $\mathbf{3 2 . 7} \pm \mathbf{4 . 7} \mathbf{~ m g} / \mathbf{L}$ & $\mathbf{1 7 . 7} \pm 5.5 \mathbf{~ m g} / \mathbf{L}$ \\
& & \\
\hline Effluent Nitrate & $\mathbf{3 3 . 2} \pm \mathbf{5 . 6} \mathbf{~ m g} / \mathbf{L}$ & $\mathbf{1 2 . 4} \pm \mathbf{5 . 3} \mathbf{~ m g} / \mathbf{L}$ \\
& & \\
\hline
\end{tabular}

This showed a clear improvement of denitrification after adding sucrose; reduce the nitrate and TN level from $33.2 \pm 5.6$ and $32.7 \pm 4.7$ $\mathrm{mg} / \mathrm{L}$ to $17.7 \pm 5.5$ and $12.4 \pm 5.3 \mathrm{mg} / \mathrm{L}$ respectively.

\section{Comparison between Simulation models and pilot-scale}

The results from the conceptual model based on SDNR batch test, the Biowin simulation, and results gotten from the pilot-plant can be summarised in Table 6 below.
The conceptual model was just a rapidassessment test designed sorely for denitrification process only and assumes complete ammonification and nitrification happened during aerobic. So despite it could accurately model the $\mathrm{TN}$ of the effluent, it failed to show that not all TN was made up by nitrate. The conceptual model in this case also accurately forecasted the nitrate accumulation inside the system during the first one month previous to adding sucrose (Figure 3).

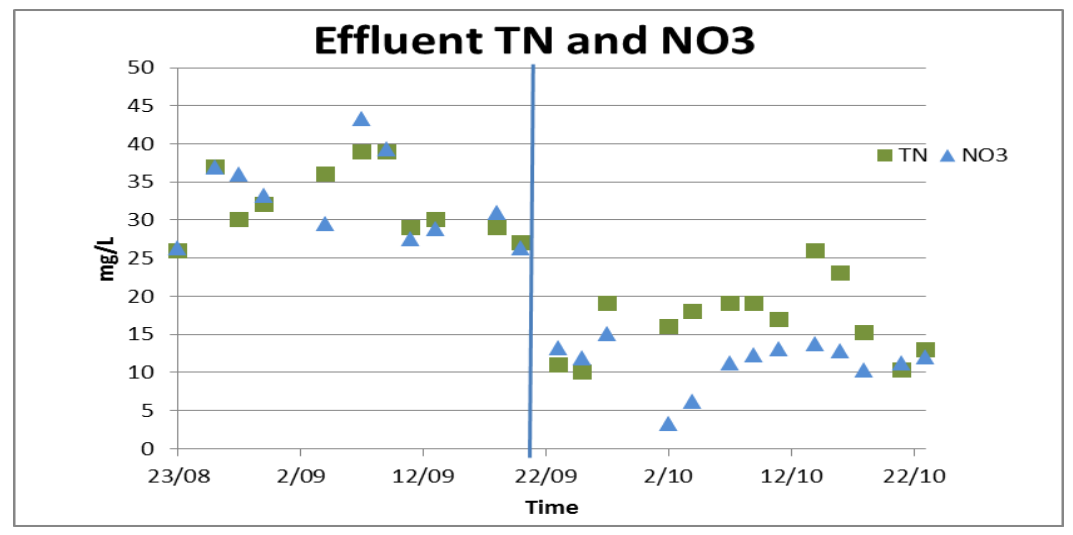

Figure 3. The pilot-plan performance

Table 6. Comparison between simulations and results from pilot-scale run

\begin{tabular}{|l|c|c|c|c|}
\hline \multirow{2}{*}{} & \multicolumn{2}{|c|}{ Before adding sucrose } & \multicolumn{2}{c|}{ After adding sucrose } \\
\cline { 2 - 5 } & $\mathrm{TN}(\mathrm{mg} / \mathrm{L})$ & $\mathrm{NO}_{3}-\mathrm{N}(\mathrm{mg} / \mathrm{L})$ & $\mathrm{TN}(\mathrm{mg} / \mathrm{L})$ & $\mathrm{NO}_{3}-\mathrm{N}(\mathrm{mg} / \mathrm{L})$ \\
\hline Conceptual model & - & - & $\mathbf{1 7 . 7} \pm \mathbf{2 . 2}$ & $17.7 \pm 2.2$ \\
\hline Biowin Simulation & $31.8 \pm 8.1$ & $25.1 \pm 4.9$ & $\mathbf{2 3 . 7} \pm \mathbf{1 0 . 3}$ & $16.5 \pm 6.0$ \\
\hline Actual results from the Pilot-scaled & $32.7 \pm 4.7$ & $3.2 \pm 5.6$ & $\mathbf{1 7 . 7} \pm \mathbf{5 . 5}$ & $12.4 \pm 5.3$ \\
\hline
\end{tabular}


The Biowin simulation on the other hand showed its capability to simulate the system previous to adding sucrose. It also showed a clear improvement on denitrification after added sucrose (nitrate reduced from $31.8 \pm 8.1 \mathrm{mg} / \mathrm{L}$ to $23.7 \pm 10.3 \mathrm{mg} / \mathrm{L}$ ). It however failed to accurately simulate the effluent quality after adding sucrose. This most likely was due to the simulation was

\section{CONCLUSION}

The major findings from these experiments are:

Sludge that has acclimated with sucrose for 24 hours provided much higher SDNR than without, increasing the SDNR by $47 \%$ for post-anoxic denitrification and by $116 \%$ for pre-anoxic denitrification.

2. After added sucrose to the anoxic zone, and left the sludge being acclimated, the SDNR of preanoxic denitrification set-up will be $2.72 \mathrm{mg} \mathrm{NO}{ }^{-}$ $\mathrm{N} / \mathrm{g}$ MLVSS/h, roughly $69 \%$ higher than of postanoxic denitrification set-up (of $1.64 \mathrm{mg} \mathrm{NO}-\mathrm{N} / \mathrm{g}$ MLVSS/h) carried out with default constants for denitrifier (e.g. growth yield efficiency, growth rate, decay rate.....) even when previous study showed that adding external carbon do affect denitrifier's microbiology and stoichiometry [7]. Hence more study will needed to be done on this to produce a more accurate Biowin simulation.

3. If a system influent has high influent $\mathrm{TN}$ and low $\mathrm{C} / \mathrm{N}$ ratio, adding sucrose into the pre-anoxic zone will significantly improve the denitrification process, improve the $\mathrm{TN}$ in effluent, reduce it from $32.7 \pm 4.7 \mathrm{mg} / \mathrm{L}$ down to $17.7 \pm 5.5 \mathrm{mg} / \mathrm{L}$

4. The conceptual model based on the SDNR batch test could fairly accurately simulate the pilot plant nitrate removal.

5. May need to find the microbiology and stoichiometry constants (e.g. growth yield efficiency, growth rate, decay rate etc.) of denitrified utilising sucrose to simulate a more accurate Biowin model.

\section{Ảnh hưởng của đường lên quá trình khử ni tơ thông qua mô phỏng, thí nghiệm theo mẻ trong phòng thí nghiệm và vận hành nhà máy pilot}

- Phùng Anh Đức

- M. Othman

- J. Yulian

RMIT, Melbourne, VIC, Australia

\section{TÓM TÁT}

Mục đích của nghiên cứu này là đánh carbon bên ngoài lên quá trình khử nitơ. Tốc giá ảnh hưởng của đường như nguồn độ khử nitơ (SDNR) được xác định bằng các 
thí nghiệm theo mẻ cho thấy sự thích nghi với đường có thể làm tăng SDNR lên $47 \%$ và $116 \%$ tại vùng sau và trước khi khử nito' thiếu khí, tương ứng. Việc sử dụng đường trong vùng trước khi khử thiếu khí dẫn đến SDNR là 2,72 $\pm 0,15 \mathrm{mg}$ NO3-N/g MLVSS/h, cao hơn 2.1 lần so với trường hợp không bổ sung nguồn carbon bên ngoài và cao hơn 1,7 lần so với trường hợp bổ sung đường vào vùng sau khi khử thiếu khí.

Thí nghiệm cũng đã nghiên cứu ảnh hưởng của đường lên hệ thống trước khi khử nitơ thiếu khí với tỷ lệ các bon trên nitơ $(C / N)$ trong nước thải thấp. Điều này đã được thực hiện thông qua hai mô hình mô phỏng (mô hình cơ sở và Biowin) trước khi vận hành thử nghiệm trên nhà máy pilot. Thí nghiệm với nước thải trên nhà máy pilot cho thấy nồng độ $N$ tổng giảm rõ rệt từ $32,7 \pm 4.7 \mathrm{mg} / \mathrm{L}$ xuống 17,7 $\pm 5,5 \mathrm{mg} / \mathrm{L}$ sau khi bổ sung thêm đường. Kết quả cũng cho thấy mô hình cơ sở đã mô phỏng chính xác hơn so với mô hình Biowin trong trường hợp này.

Từ khóa: Quá trình khử nitơ, nguồn carbon bên ngoài, Biowin, mô phỏng.

\section{REFERENCES}

[1]. Makinia, J., Czerwionka, K., Oleszkiewicz, J., Kulbat, E. \& FudalaKsiazek, S. 2011. A distillery by-product as an external carbon source for enhancing denitrification in mainstream and sidestream treatment processes. Water Science and Technology, 64, 2072-2079.

[2]. Meyer, R. L., Zeng, R. J., Giugliano, V. \& Blackall, L. L. 2005. Challenges for simultaneous nitrification, denitrification, and phosphorus removal in microbial aggregates: Mass transfer limitation and nitrous oxide production. FEMS Microbiology Ecology, 52, 329-338.

[3]. Puig, S., Coma, M., Van Loosdrecht, M. C. M., Colprim, J. \& Balaguer, M. D. 2007. Biological nutrient removal in a sequencing batch reactor using ethanol as carbon source. Journal of Chemical Technology and Biotechnology, 82, 898904.

[4]. Swinarski, M., Makinia, J., Czerwionka, K., Chrzanowska, M. \& Drewnowski, J. 2009. Comparison of the effects of conventional and alternative external carbon sources on enhancing the denitrification process. Water Environment Research, 81, 896-906.

[5]. Cherchi, C., Onnis-Hayden, A., ElShawabkeh, I. \& Gu, A. Z. 2009. Implication of using different carbonsources for denitrification in wastewater treatments. Water Environment Research, 81, 788-799.

[6]. Swinarski, M., Makinia, J., Stensel, H. D., Czerwionka, K. \& Drewnowski, J. 2012. Modeling external carbon addition in biological nutrient removal processes with an extension of the international water association activated sludge model. Water Environment Research, 84, 646-655.

[7]. Dold, P., Takács, I., Mokhayeri, Y., Nichols, A., Hinojosa, J., Riffat, R., Bott, C., Bailey, W. \& Murthy, S. 2008. Denitrification with carbon addition kinetic considerations. Water Environment Research, 80, 417-427.

[8]. Peng, Y. Z., MA, Y. \& Wang, S. Y. 2007. Denitrification potential enhancement by addition of external carbon sources in a pre-denitrification process. J Environ Sci (China), 19, 284-9. 
[9]. Eddy, M. 2003. Wastewater engineering: treatment, disposal, and reuse / Metcalf \& Eddy, Inc, New York, McGraw-Hill.

[10]. Hamilton, G 2012, Bench Scale Denitrification ftudy for SUcrosolutions(TM) for Water Sugar Australia.

[11]. Mokhayeri, Y., Riffat, R., Takacs, I., Dold, P., Bott, C., Hinojosa, J., Bailey, W. \& Murthy, S. 2008. Characterizing denitrification kinetics at cold temperature using various carbon sources in lab-scale sequencing batch reactors.

[12]. Shen, J., He, R., Han, W., Sun, X., LI, J. \& Wang, L. 2009. Biological denitrification of high-nitrate wastewater in a modified anoxic/oxic-membrane bioreactor (A/OMBR). Journal of Hazardous Materials, 172, 595-600. 